10. Калориметричний пристрій для визначення питомої теплоти випаровування вологи і органічних рідин з матеріалів: пат. 84075 Україна: МПК ${ }^{8}$ G01 N25/26, G01 N25/28. № а200613266; заявл. 15.12.06; опубл. 10.09.08.

11. Никитина Л.М. Таблицы равновесного удельного влагосодержания и энергия связи влаги с материалами. - М.-Л.: «Госэнергоиздат», 1963.- $176 \mathrm{c}$.

12. Сушка древесины: справочник / Составители С. Алюшин и др. - К.: «Тристан», 2004. - 448 с.

13. Згурський А.В., Поліщук Г.Є., Кропивницька І.О. Перерозподіл пектинових речовин в овочевій сировині при виробництві морозива // Харчова промисловість. - 2011. - № 10. - С. 50-55.

14. Химический состав пищевых продуктов : справочные таблицы : в 2 кн. / Под ред. И.М. Скурихина и М.Н. Волгарева. - М.: «Агропромиздат», 1987.

15. Гупало О. П., Тушницький О. П. Хімія деревини : навч. посібник - К.: «Знання», 2008. - 276 с.

\title{
References
}

1. Lykov A. V. (1968). Teoriya sushki. Moscow: Energiya, 472.

2. Zaytsev I.D., Aseev G.G. (1988). Fiziko-khimicheskie svoystva binarnykh i mnogokomponentnykh rastvorov neorganicheskikh veshchestv: spravochnoe izdanie. Moscow: Khimiya, 416

3. Mosin O.V. Sposobnost vody k rastvoreniyu. Sayt o8ode.ru. - Available at: http://www.o8ode.ru/article/water/

4. Mikhaylik V.A. (2006). Eksperimentalnoe issledovanie gidratatsii sakharozy. Naukovi pratsi Odeskoï natsionalnoï akademiï kharchovikh tekhnologiy, no. 28, vol. 2, pp. 370-374.

5. Mikhaylik V.A., Davidova O.O., Mank V.V. (2000). Doslidzhennya gidratatsii D-glyukozi ta D-fruktozi. Proceedings of the Problemi ta perspektivi stvorennya i vprovadzhennya novikh resurso- ta energooshchadnikh tekhnologiy, obladnannya $\mathrm{v}$ galuzyakh kharchovoï i pererobnoï promislovosti (Ukraine, Kiev, October 19-21, 1999). Kiev: UDUKhT, vol.1, pp. 106.

6. Isakov V.T. Yestestvennoe $\mathrm{i}$ iskusstvennoe strukturirovanie vody. Sayt o8ode.ru. - Available at: http://www.o8ode.ru/article/learn/water_structure.htm

7. Frenks F. (1980). Voda, led i rastvory prostykh molekul. Voda v pishchevykh produktakh, eds. R.B. Dokuorta. Moscow: Pishchevaya promyshlennost, pp. 14-32

8. Brunauer S. (1948). Adsorbtsiya gazov i parov. Moscow: Gos. izdatelstvo inostrannoy literatury, 768.

9. Simatos D., Four M., Bonzhur I., Kouch M. (1980). Primenenie differentsialnogo termicheskogo analiza i differentsialnoy skaniruyushchey kalorimetrii pri izuchenii vody v pishchevykh produktakh. Voda v pishchevykh produktakh, eds. R.B. Dokuorta. Moscow: Pishchevaya promyshlennost, pp. 156-170.

10. Snezhkin Yu.F., Dekusha L.V., Dubovikova N.S., Grishchenko T.G., Vorobyov L.Y., Boryak L.A. (2008). UKR. Patent No. 84075.

11. Nikitina L.M. (1963). Tablitsy ravnovesnogo udelnogo vlagosoderzhaniya i energiya svyazi vlagi s materialami. - MoscowLeningrad: Gosenergoizdat, 176.

12. Alyushin S. et al. (2004). Sushka drevesiny: spravochnik. Kiev: Tristan, 448.

13. Zgurskiy A.V., Polishchuk G.C., Kropivnitska I.O. (2011). Pererozpodil pektinovikh rechovin v ovocheviy sirovini pri virobnitstvi moroziva . Kharchova promislovist, no. 10, pp. 50-55

14. Skurikhin I.M., Volgarev M.N. (1987). Khimicheskiy sostav pishchevykh produktov. Spravochnye tablitsy, 2 vol. Moscow: Agropromizdat.

15. Gupalo O. P., Tushnitskiy O. P. (2008). Khimiya derevini. Navchflnyi posibnik. Kiev: Znannya, 276.

\section{ДІЄТИЧНА ДОБАВКА ІМУНОТРОПНОЇ ДІЇ НА ОСНОВІ ПРОДУКТІВ ДЕСТРУКЦЇ̈ ПРОБІОТИЧНИХ БАКТЕРІАЛЬНИХ КУЛЬТУР}

\author{
Капустян А. І., к.т.н., доцент, Черно Н. К., д.т.н., професор \\ Одеська національна академія харчових технологій, м. Одеса
}

\begin{abstract}
Анотація. У роботі розглянуто можливість отримання імунотропної дієтичної добавки на основі низькомолекулярних продуктів деградації пептидогліканів клітинних стінок пробіотичних бактерій. Встановлено раціональні режими автолізу біомаси як первинного етапу деструкиії пептидогліканів бактеріальних клітинних стінок. Показано, щзо найбільш інтенсивний лізис клітин відбувається при експозииії культуральної рідини при 90 ${ }^{\circ}$ протягом 15 хв після 8-ї години культивування, про щчо свідчить ма-

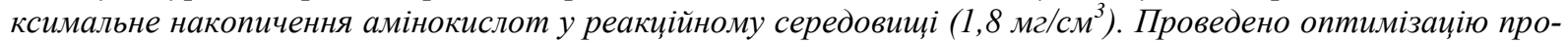
иесу деструкиії пептидогліканів бактеріальних клітин, які піддавали лізису, ферментним препаратом панкреатином. Ефективність ферментолізу визначали за накопиченням імунотропних низькомолекулярних пептидів залежно від концентрації ферменту $\left(C_{E}\right)$, субстрату $\left(C_{S}\right)$ в реакційній суміші та тривало-

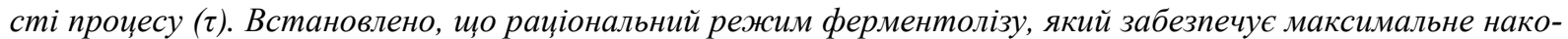
пичення низькомолекулярних пептидів $(0,569$ мг/см², досягається за наступних значень факторів: $C_{E}=12,5 \mathrm{мг} / \mathrm{cm}^{3}, C_{S}=70,0 \mathrm{мг} / \mathrm{cm}^{3}, \tau=245,6$ хв. Зразок низькомолекулярних пептидів, отриманий за раціональних режимів деструкції, досліджено методом IЧ-спектроскопї. Встановлено, щзо у його IЧ-спектрі присутні смуги поглинання, які відповідають коливанням аміногруп, пептидних зв'язків, піранозної форми глюкози, залишки якої входять до складу мурамової кислоти, та N-ацетилглюкозаміну пептидоглікану. Приведено загальну схему, що ілюструє послідовність прочесів виробництва імунотропної дієтичної
\end{abstract}


добавки .У дослідах на щурах встановлено ефективну дозу отриманої дієтичної добавки -0,06 мг/кг маси тіла.

Ключові слова: дієтична добавка, пробіотичні культури, пептидоглікани, муропептиди, автоліз, ферментоліз, панкреатин.

\title{
DIETARY IMMUNOTROPIC SUPPLEMENT BASED ON THE DESTRUCTION PRODUCTS OF PROBIOTIC BACTERIAL CULTURES
}

\author{
Kapustian A. I. PhD in Tech.Sci, Cherno N. K., Dr. in Tech.Sci \\ Odessa National Academy of Food Technologies, Odesa, Ukraine
}

\begin{abstract}
The possibility of obtaining an immunotropic dietary supplement based on low molecular weight degradation products of cell wals peptidoglycans of lactic and bifidobacteria composition has been considered. Rational regimes of autolysis of biomass as the primary stage of degradation of peptidoglycans of bacterial cell walls have been established. It was shown that the most intensive lysis of cells takes place when the culture liquid is treated at a temperature of $90{ }^{\circ} \mathrm{C}$ for the 8 th hour of cultivation, as indicated by the maximum accumulation of amino acids in the reaction medium $\left(1.8 \mathrm{mg} / \mathrm{cm}^{3}\right)$. Optimization of the destruction process of bacterial cell peptidoglycans exposed to lysis, by enzyme preparation with pancreatin, was carried out by the mathematical planning method of the multifactorial experiment. The effectiveness of enzymatic hydrolysis was determined by the accumulation of immunotropic low molecular weight peptides, depending on the concentration of the enzyme $\left(C_{E}\right)$, the substrate $\left(C_{S}\right)$ in the reaction mixture and the duration of the process $(\tau)$. The rational value of the factors $C_{E}, C_{S}$ and $\tau$ that provide the maximum concentration of low molecular weight peptides $\left(0.569 \mathrm{mg} / \mathrm{cm}^{3}\right)$ in the enzymatic hydroltsate are $C_{E}=12.5 \mathrm{mg} / \mathrm{cm}^{3}, C s=70.0 \mathrm{mg} / \mathrm{cm}^{3}, \tau=245.6 \mathrm{~min}$. A sample of low molecular weight peptides obtained from rational degradation regimes was investigated using the IR spectroscopy method. It has been established that in its spectrum absorption bands corresponding to fluctuations of amino groups, peptide bonds are presentred, which, in fact, take place in the structure of peptides. Fluctuations of the pyranose glucose form, which is included in the muramic acid and Nacetylglucosamine of peptidoglycan, have also been observed. The general scheme of the sequence of production processes of an immunotropic dietary supplement has been given. In animal experiments, it has been established that this additive, in accordance with the classification of chemicals substances to the degree of danger, belongs to class 4 (low-toxic substances). The effective dose of the obtaned dietary supplement is $0.06 \mathrm{mg} / \mathrm{kg}$ body weight.
\end{abstract}

Key words: dietary supplement, probiotic cultures, peptidoglycans, muropeptides, autolysis, enzymatic hydrolysis, pancreatin.

Постановка проблеми та її зв'язок з найважливішими науковими і практичними завданнями. Реактивне збільшення випадків захворювання серед населення, викликаних бактеріальними та вірусними збудниками, провокується пригніченням функціональної активності імунної системи. На фармакологічному ринку України присутні ряд імунологічних препаратів природного, штучного або напівштучного походження. Найбільш поширеними серед природних є екстракти деяких лікарських рослин, пробіотики, інтерферон та його похідні. Імунологічною активністю володіють також продукти переробки дріжджів та пробіотичних бактерій, що містять відповідно такі біологічно-активні сполуки як глюкани та фрагменти пептидогліканів. Особливе значення надається низькомолекулярним продуктам деградації пептидогліканів - муропептидам, оскільки вони здатні ініціювати та активізувати еволюційно закріплений механізм вродженої імунної відповіді [1-3]. Використання їх у складі дієтичних добавок та харчових інгредієнтів 3 метою нутрітивної підтримки населення зі зниженим імунним статусом є вельми актуальним [4].

Аналіз останніх досліджень та публікацій. Муропептиди - складові пептидогліканів бактеріальних клітин, які використовують переважно у складі імунотропних фармацевтичних препаратів («Бронхомунал», «Імудон», «ІРС-19», «Постерізан», «ГМДП», «Ліастен») [5-7], але у літературі відсутня інформація про використання їхніх аналогів у якості імунотропних харчових інгредієнтів та у складі дієтичних добавок. У першу чергу це пов'язано зі складністю процесу виділення муропептидів, оскільки більшість методів їхнього отримання досить складні у виконанні, особливо у промислових масштабах. Вони $є$ багатостадійними, із застосуванням специфічних та високовартісних реактивів. Окрім того, напрацьовано методи дезінтеграції переважно патогенних мікроорганізмів, використання фрагментів яких у харчування може бути небезпечним. Перевагу доцільно віддавати пробіотичним культурам бактерій, оскільки вони визнані безпечними і мають «GRAS» статус (generally recognized as safe). До того ж, пробіотичні мікрооорганізми в переважній більшості містять до 70\% пептидоглікану, що є передумовою збільшення виходу муропептидів у результаті деструкції клітинних стінок бактерій.

Серед існуючих методів дезінтеграції бактеріальних клітин, перевагу надають як правило ензиматичним та хімічним факторам впливу у поєднанні з обробкою ультразвуком. Так, в роботі [8] здійснювали гідроліз Lactobacillus bulgaricus послідовною обробкою пепсином, лізоцимом і ультразвуком. У праці [9] 
отримано гідролізат молочнокислих бактерій штаму L. acidophilus У 2505 термокислотним методом. Описано також спосіб отримання препарату [10], що містить глікопептиди, який передбачає напрацювання біомаси клітин L. bulgaricus на спеціальних поживних середовищах, обробку біомаси трипсином, дезінтеграцію біомаси ультразвуком, повторну обробку біомаси трипсином і пепсином, центрифугування, гідроліз лізоцимом, хроматографію. У роботах [11,12] деградацію пептодигліканів мікроорганізмів здійснювали за допомогою високоспецифічних ендо- та екзопротеаз бактеріального походження, в тому числі мутанолізином.

Варто зазначити, що одним із шляхів зменшення стадійності процесу отримання імунотропних складових пептидогліканів клітинних стінок бактерій є проведення процесів автолізу [13-15], які при отриманні фрагментів пептидогліканів у наведених роботах не використовувались.

У даній роботі розглянуто можливість отримання імунотропних харчових інгредієнтів на основі продуктів деструкції клітинних стінок пробіотичних культур шляхом застосування процесу автолізу та ферментолізу. Завдяки автолітичним змінам бактеріальних клітин можна нівелювати необхідність первинної деструкції бактерій із залученням фізичних методів впливу, що значно скоротить кількість технологічних операцій, i, в результаті, собівартість дієтичної добавки. У роботі не передбачається застосування агресивних хімічних реагентів, яке є недопустимим у харчових технологіях.

Мета роботи - розроблення загальної схеми послідовності технологічних процесів для отримання дієтичної добавки імунотропної дії на основі продуктів ферментолізу пептидогліканів пробіотичних бактерій, визначення раціональних параметрів ключових процесів деструкції пептидогліканів - автолізу та ферментолізу, проведення медико-біологічних випробувань отриманої добавки у дослідах на тваринах.

Матеріали та методи досліджень. Дослідження проводили на кафедрі харчової хімії та експертизи Одеської національної академії харчових технологій (Одеса, Україна), у науковій лабораторії НВП «Аріадна» (Одеса, Україна), лабораторії Державного науково-дослідного контрольного інституту ветеринарних препаратів та кормових добавок (м. Львів, Україна).

У роботі використовували композицію молочнокислих та біфідобактерій (МКБ та ББ), що представляє собою суму тест-культур: Lactobacillus acidophilus, Lactobacillus delbrueckii subsp. bulgaricus, Bifidobacterium bifidum, Lactococcus lactis subsp. lactis, Lactococcus lactis subsp. cremoris, Streptococcus thermophilus із колекції НВП «Аріадна». Дана бактеріальна композиція має комерційну назву «Бактеріальна закваска Симбінорм».

Ферментативну деградацію пептидогліканів клітинних стінок бактеріальної композиції здійснювали обробкою ферментним препаратом «Панкреатин» (Тернофарм, Тернопіль) 3 протеолітичною активність 370 Од.

На першій стадії експерименту проводили вирощування першої генерації кожної з бактеріальних монокульутур окремо на спеціальних живильних середовищах, розроблених підприємством «Аріадна». Бактеріальні штами вирощували в стерильних умовах при $37^{\circ} \mathrm{C}$. Після досягнення чисельності бактерій 5-9·1 ${ }^{9}$ КУО, культуральні рідини поєднували, додавали живильне середовище та вирощували другу генерацію бактерій в стерильних умовах при $37^{\circ} \mathrm{C}$. Автоліз біомаси досліджували починаючи 3 4-ї год культивування протягом 10 год при експозиції культуральної рідини при 70 та $90^{\circ} \mathrm{C}$ протягом 15 хв. Хід автолізу контролювали за накопиченням амінокислот у реакційному середовищі. Вміст амінокислот визначали за допомогою формольного титрування [16].

Для проведення ферментолізу здійснювали виділення бактеріальних клітин із культуральної рідини шляхом центрифугування протягом 15 хв при 8000 хв$^{-1}$. Осад клітин відмивали дистильованою водою та ресуспендували. Ферментоліз проводили за температури $37^{\circ} \mathrm{C}$ та $\mathrm{pH}=7,4$. Варіювали масову частку ферменту у межах 0,1 - $20 \mathrm{мг} / \mathrm{cm}^{3}$, субстрату (клітин МКБ) у межах $10-70 \mathrm{Mг} / \mathrm{cm}^{3}$, та тривалість інкубації реакційної суміші - $10-300$ хв.

Ферментоліз зупиняли екстреним нагріванням до температури $100{ }^{\circ} \mathrm{C}$, суміш охолоджували, центрифугували протягом 10 хв при 8000 хв$^{-1}$, проводили декантацію. У надосадовій рідині контролювали вміст низькомолекулярних пептидів (НМП) методом Бенедикта [16] після осадження високомолекулярних білків $10 \%$-вим розчином три хлороцтової (ТХО) кислоти. Відомо, що пептиди з молекулярною масою до 1500 Да не осаджуються розчинами ТХО кислоти та можуть належати до сполук мурамилпептидного ряду, що володіють високою імунотропною активністю [9].

Із метою скорочення кількості дослідів і отримання достовірних даних про закономірності процесу ферментолізу композиції МКБ та ББ доцільно використовувати методи математичного планування багатофакторних експериментів. Для цього було реалізовано план повного трьохфакторного експерименту ПФЕ-2 ${ }^{3}$.

Наведена на рис. 1 схема, наочно демонструє, що для визначення оптимальних параметрів деструкції пептидогліканів клітинних стінок молочнокислих бактерій з метою отримання низькомолекулярних пептидів, необхідно встановити вплив концентрації ферменту $\left(\mathrm{C}_{\mathrm{E}} \mathrm{M \Gamma} / \mathrm{cm}^{3}\right)$, концентрації субстрату (клітин молочнокислих бактерій, $\mathrm{C}_{\mathrm{S}}$, $\left.\mathrm{s \Gamma} / \mathrm{cm}^{3}\right)$ і тривалості процесу ферментативної деструкції ( $\tau, \mathrm{xв)}$. 


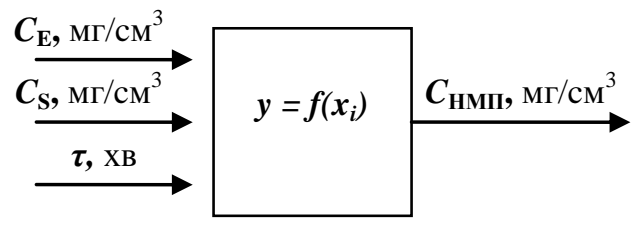

\section{Рис. 1. Параметрична схема ферментативного гідролізу.}

Таким чином, вихідним параметром є концентрація низькомолекулярних продуктів ферментативної деструкції клітинних стінок - пептидів у ферментолізаті $\left(\mathrm{C}_{\text {нмп, }}\right.$ мг/см$\left.{ }^{3}\right)$. Рівні та інтервали варіювання факторів при ферментолізі наведено в табл. 1.

Таблиця 1

Рівні та інтервали варіювання факторів при ферментолізі пептидогліканів лізату пробіотичних культур

\begin{tabular}{|l|c|c|c|}
\hline \multirow{2}{*}{$\begin{array}{c}\text { Рівні та інтервали } \\
\text { варіювання факторів }\end{array}$} & \multicolumn{3}{|c|}{ Фактори } \\
\cline { 2 - 4 } & $C_{E}, \mathrm{M \Gamma} / \mathrm{cm}^{3}$ & $C_{S}, \mathrm{M} / \mathrm{cm}^{3}$ & $\tau$, хв \\
\hline Нижній рівень & 0,1 & 10 & 10 \\
\hline Верхній рівень & 20,0 & 70 & 360 \\
\hline Нульовий рівень & 10,05 & 40 & 185 \\
\hline Інтервали & 9,95 & 30 & 175 \\
\hline
\end{tabular}

Однорідність результатів дослідів оцінювали за критерієм Кохрена, щоб виключити вплив систематичних помилок, викликаних зовнішніми умовами і зменшити випадкові помилки, досліди було рандомізовано [17].

ІЧ-спектри зразків реєстрували у діапазоні довжин хвиль від 4000 до $400 \mathrm{~cm}^{-1}$ на спектрометрі 3 фурьє-перетворювачем FTIR IR Affinity-1, Shimadzu (Япония). Зразки для IЧ-спектроскопії готували за допомогою йонообмінної хроматографії з використанням йонообмінника КУ-2. Для цього ферментолізат, отриманий за раціональних умов, обробляли $10 \%$-вим розчином ТХО, центрифугували протягом 10 хв при 8000 хв1ㅡㄹ, осад, що містив високомолекулярні сполуки, видаляли, а супернатант пропускали через йонообмінну колонку ( $\mathrm{H}=30 \mathrm{~cm}, \mathrm{D}=1,8 \mathrm{~cm})$. Отриманий елюат містив амінокислоти, низькомолекулярні пептиди та був позбавлений від кислот, нейтральних вуглеводів та солей.

Результати дослідження та їхнє обговорення.Клітинні стінки мікроорганізмів, особливо грампозитивних, до яких і відносяться МКБ та ББ, володіють високою механічною міцністю, що створює значну перепону для їхньої дезінтеграці. Враховуючи здатність бактеріальних клітин до автолізу його було використано як первинний етап деструкції пептидогліканів їхніх клітинних стінок.

Для протікання процесів автолізу бактеріальну масу в процесі культивування піддавали температурній обробці. Хід автолітичних змін біомаси досліджували за накопиченням вільних амінокислот у культуральній рідині (рис. 2).

Встановлено, що найвищий вміст амінокислот, а, відповідно, і ступінь деградації композиції МКБ та ББ має місце при обробці культуральної рідини за температури $90^{\circ} \mathrm{C}$ після 8 -ми годин культивування, що відповідало закінченню логарифмічної фази росту бактерій [18]. Це узгоджується з даними літератури про те, що наприкінці логарифмічної фази росту бактеріальні клітини $є$ найбільш вразливими до дії агресивних факторів, що можуть порушити цілісність бактеріальної клітини шляхом руйнування їхньої захисної оболонки, або часткової перфорації бактеріальної стінки [19].

До того ж, проведення автолізу на цій стадії росту клітин дозволяє мінімізувати вміст бактеріальних нуклеїнових кислот у складі культуральної рідини, адже відомо, що наприкінці саме цієї фази росту їхній вміст мінімальний [19].

Автолітичні зміни біомаси не приводять до отримання низькомолекулярних муропептидів, тому для досягнення цієї мети, застосували ферментативний гідроліз пептидоглікану автолізату біомаси ферментним препаратом панкреатином.

У складі панкреатину міститься ряд екзо- та ендопротеаз, що здатні розщеплювати специфічні пептидні зв’язки високомолекулярного пептидоглікану клітинних стінок бактерій, утворюючи продукти його деградації: амінокислоти, низькомолекулярні муропептиди, що володіють потужним імунотропним ефектом. 


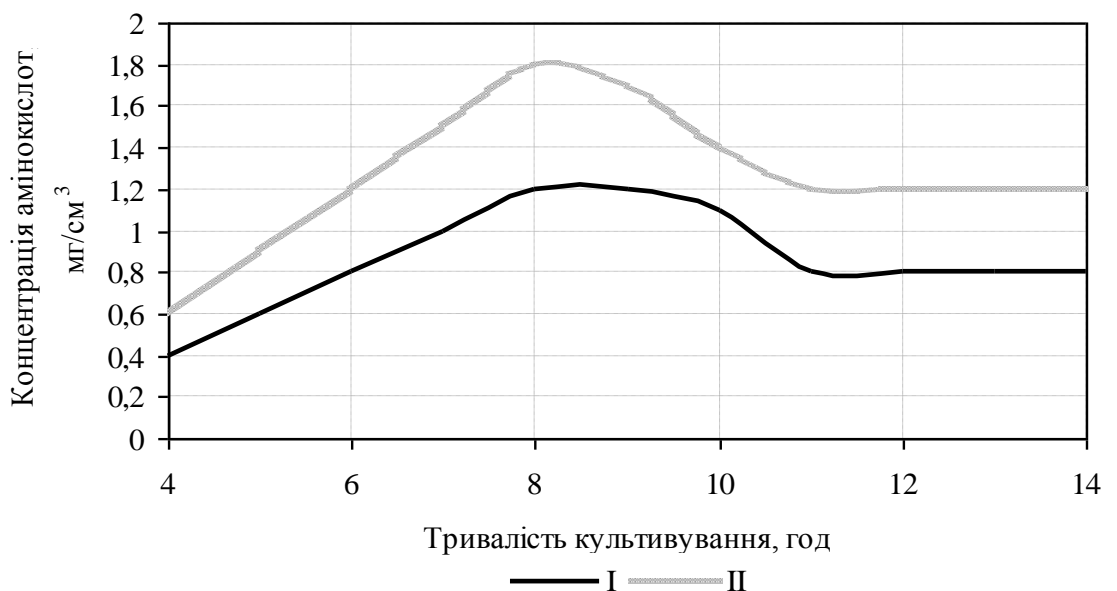

Рис. 2. Накопичення амінокислот при автолізі композиції МКБ та ББ в залежності від тривалості культивування та температурної обробки $\left(\mathrm{I}-70^{\circ} \mathrm{C}, \mathrm{II}-90^{\circ} \mathrm{C}\right)$.

Для визначення раціональних умов ферментолізу з метою отримання максимальної кількості НМП проведено п'ятнадцять дослідів, умови яких наведено у табл. 2, де, крім матриці плану експериментів, наведено також середні (за трьома паралельними) значення результатів дослідів $\mathrm{C}_{\mathrm{Hмп}}\left(y_{\text {сер }}\right)$, розрахункові значення $\left(y_{\mathrm{p}}\right)$ за рівнянням регресії та відносні похибки $(\delta)$ між ними.

Таблиця 2

Матриця плану дослідів і результати залежності вмісту НМП у ферментолізаті при різних умовах ферментативної деструкції

\begin{tabular}{|c|c|c|c|c|c|c|}
\hline \multirow{2}{*}{$\begin{array}{c}\text { Номер } \\
\text { досліду }\end{array}$} & \multicolumn{3}{|c|}{ Умови дослідів } & \multicolumn{3}{c|}{ Результати } \\
\cline { 2 - 7 } & $C_{E}, \mathrm{M \Gamma} / \mathrm{cm}^{3}$ & $C_{S}, \mathrm{M \Gamma} / \mathrm{cm}^{3}$ & $\tau$, хв & $y_{\text {сер }, \mathrm{M \Gamma} / \mathrm{cm}^{3}}$ & $y_{\mathrm{p}}, \mathrm{Mг} / \mathrm{cm}^{3}$ & $\delta, \%$ \\
\hline 1 & 0,1 & 10 & 10 & 0,019 & 0,018 & 3,83 \\
\hline 2 & 20 & 10 & 10 & 0,092 & 0,089 & 3,40 \\
\hline 3 & 0,1 & 70 & 10 & 0,085 & 0,085 & 0,32 \\
\hline 4 & 20 & 70 & 10 & 0,159 & 0,156 & 1,97 \\
\hline 5 & 0,1 & 10 & 360 & 0,095 & 0,092 & 2,66 \\
\hline 6 & 20 & 10 & 360 & 0,163 & 0,163 & 0,04 \\
\hline 7 & 0,1 & 70 & 360 & 0,372 & 0,369 & 0,68 \\
\hline 8 & 20 & 70 & 360 & 0,439 & 0,440 & 0,24 \\
\hline 9 & 0,1 & 40 & 185 & 0,341 & 0,347 & 1,62 \\
\hline 10 & 20 & 40 & 185 & 0,412 & 0,417 & 1,24 \\
\hline 11 & 10,05 & 10 & 185 & 0,371 & 0,368 & 0,69 \\
\hline 12 & 10,05 & 70 & 185 & 0,545 & 0,540 & 0,83 \\
\hline 13 & 10,05 & 40 & 10 & 0,153 & 0,160 & 4,39 \\
\hline 14 & 10,05 & 40 & 360 & 0,335 & 0,339 & 1,17 \\
\hline 15 & 10,05 & 40 & 185 & 0,458 & 0,454 & 0,77 \\
\hline
\end{tabular}

Після реалізації дослідів методом найменших квадратів та послідовного регресійного аналізу, реалізованих у програмі PLAN [17], було отримане рівняння регресії у кодованих змінних, яке адекватно (за критерієм Фішера) описує залежність $C_{\mathrm{Hмп}}$ від факторів $C_{\mathrm{E}}, C_{\mathrm{S}}$ та $\tau$ :

$Y=0,454+0,0353 x_{1}+0,086 x_{2}+0,0896 x_{3}-0,0726 x_{1}^{2}-0,2051 x_{3}^{2}+0,0525 x_{2} x_{3}$,

де $x_{1}, x_{2}, x_{3}$ - кодовані значення факторів відповідно $C_{E}, C_{S}$ та $\tau$, які визначаються за такими співвідношеннями: $x_{1}=\left(C_{E}-10,05\right) / 9,95 ; x_{2}=\left(\mathrm{C}_{\mathrm{S}}-40\right) / 30 ; x_{3}=(\tau-185) / 175$.

Використовуючи отримане рівняння були визначені раціональні значення факторів $C_{E}, C_{S}$ та $\tau$, які забезпечують максимальну концентрацію низькомолекулярних пептидів $\mathrm{C}_{\mathrm{Hмп}}$ у ферментолізаті: $C_{\mathrm{E}}=12,5 \mathrm{мг} / \mathrm{cm}^{3}, C_{\mathrm{S}}=70,0 \mathrm{мг} / \mathrm{cm}^{3}, \tau=245,6 \mathrm{xв}, C_{\mathrm{HM}}=0,569 \mathrm{мг} / \mathrm{cm}^{3}$. Зразок НМП, отриманий за раціональних умов ферментолізу, вивчали за допомогою методу ІЧ-спектроскопії на предмет наявності у його структурі функціональних груп та специфічних зв'язків, притаманних імунотропним муропептидам (рис.3). В ІЧ-спектрі НМП виявлено низку інтенсивних смуг поглинання, характерних для коливань специфічних функціональних груп та зв'язків, притаманним низькомолекулярним продуктам деградації пептидогліканів клітинних стінок бактерій. Так, в області спектру 3380-3450 см-1 присутня широка смуга, яка свідчить про наявність вільних аміногруп. Смуга при $1642 \mathrm{~cm}^{-1}$ відповідає за коливання пептидних зв'язків, при $1155 \mathrm{~cm}^{-1}$ - піранозної форми глюкози, при $1013 \mathrm{~cm}^{-1}-\beta$-глікозидного зв’язку [20]. 


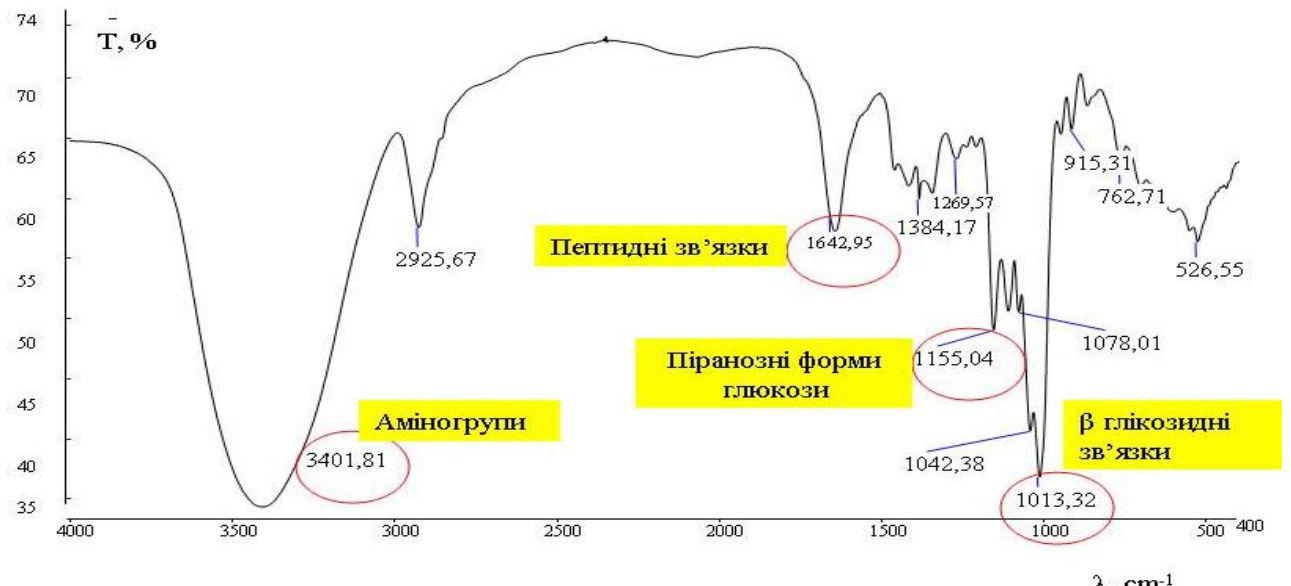

Рис. 3. ІЧ-спектр НМП ферментолізату.

Результати досліджень низькомолекулярних компонентів ферментолізату свідчать, що за визначених раціональних умов деструкції пептидогліканів композиції МКБ та ББ досягнуто головної мети - отримано продукти деструкції, які за своєю хімічною структурою та молекулярною масою відповідають муропептидам, що володіють потужним імунотропним ефектом. На рис. 4 представлено послідовність основних процесів виробництва дієтичної добавки на основі низькомолекулярних продуктів деградації пептидогліканів пробіотичних бактерій.

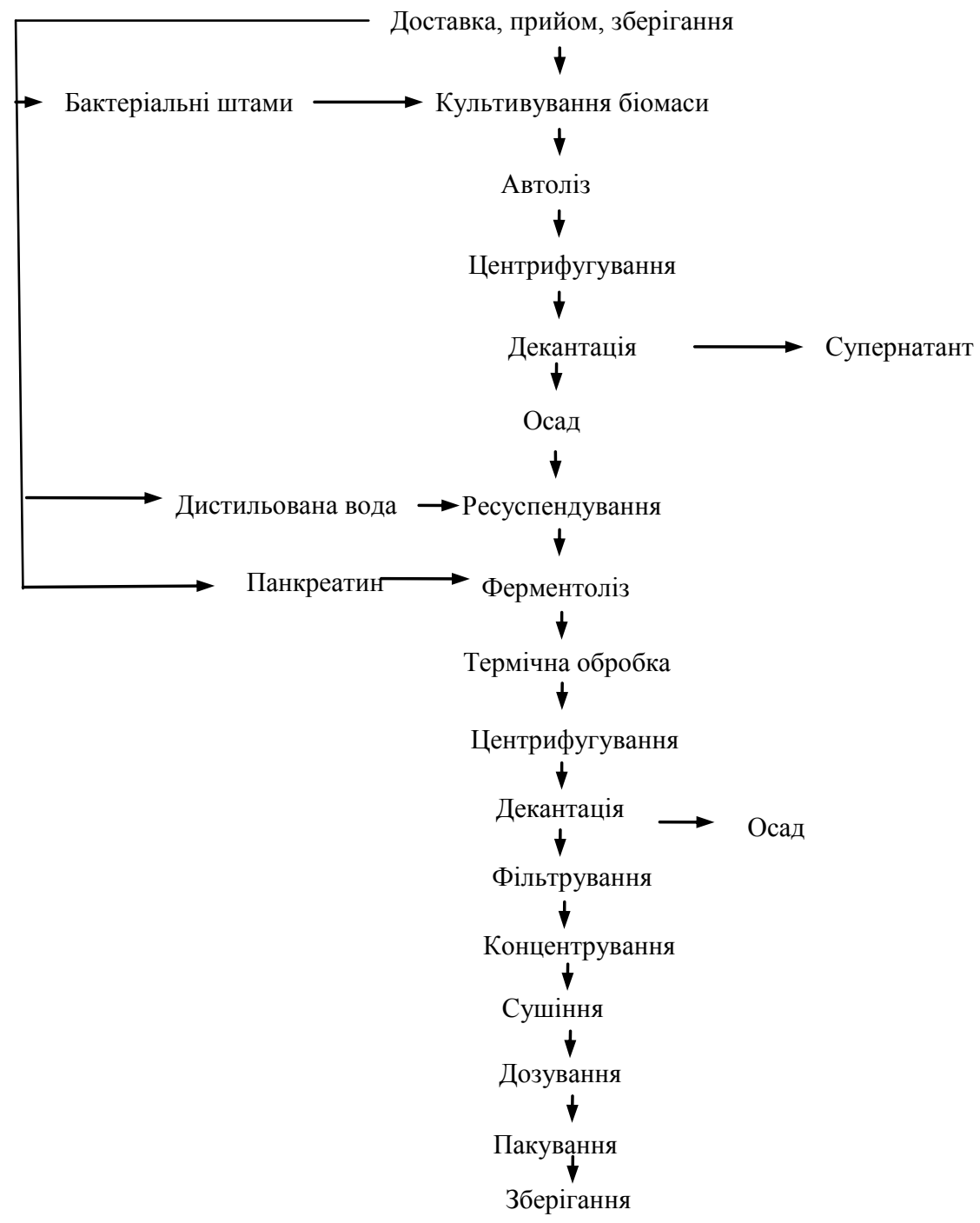

Рис. 4. Загальна схема виробництва дістичної добавки імунотропної дії на основі продуктів деградації пептидогліканів клітинних стінок пробіотичних бактерій. 
За розробленою схемою отримано дослідну партію дієтичної добавки для медико-біологічних досліджень, які проводили на білих безпорідних щурах віком 2-3 місяці, масою тіла 160-180 г, що утримувались на стандартному раціоні віварію. Встановлено, що вона ефективно впливає на динаміку гематологічних, біохімічних та імунологічних показників, результатами гістологічних та морфологічних досліджень доведено збільшення імунологічної реактивності тимуса. Уведення у раціон щурів розробленої добавки сприяє зростанню кількості фагоцитів та їхньої поглинальної здатності. Відмічено зростання кількості $\gamma$-глобулінів у тварин, що вказувало на активацію білоксинтезувальної функції печінки [21].

Отже, отримані результати свідчать про доцільність здійснення подальших досліджень із розроблення технології дієтичної добавки на основі низькомолекулярних продуктів деградації пептидогліканів пробіотичних бактерій, здійснення іiі клінічної апробації та визначення шляхів іiї використання у харчових раціонах.

Висновки. У роботі визначено раціональні параметри ключових процесів деструкції пептидогліканів композиції МКБ та ББ - автолізу та ферментолізу. Результати ІЧ-спектроскопії довели, що у структурі продуктів ферментолізу (НМП), містяться специфічні функціональні групи та хімічні зв'язки, притаманні муропептидам. Розроблено загальну схему послідовності технологічних процесів отримання дієтичної добавки імунотропної дії на основі продуктів деградації пептидогліканів клітинних стінок пробіотичних культур. У дослідах на тваринах визначено іiї ефективну дозу - 0,06 мг/кг маси тіла. Показано їі позитивний вплив на динаміку гематологічних, біохімічних та імунологічних показників крові, білоксинтезувальну функцію печінки. Доцільно проведення подальших досліджень із розроблення технології дієтичної добавки на основі низькомолекулярних продуктів деградації пептидогліканів пробіотичних бактерій, здійснення її клінічної апробації та визначення шляхів використання у харчових раціонах.

\section{Лiтература:}

1. Traub S. MDP and other muropeptides - direct and synergistic effects on the immune system. J. Endotoxin Res. 2006. V. 12(2).P. 6985. DOI: $10.1179 / 096805106 \times 89044$

2. Matsui K., Ikeda R. Peptidoglycan in combination with muramyldipeptide synergistically induces an interleukin-10-dependent T helper 2-dominant immune response // Microbiol Immunol. 2014. V. 58. P. 260-265. DOI:10.1111/1348-0421.12139

3. Cherno N., Kapustyan A. Immunological properties of the bacterial origin compounds // Food science and technology. 2016.-10(3). P. 19-28. DOI: http://dx.doi.org/10.15673/fst.v10i3.175

4. Капустян А.И., Черно Н.К. Перспективы использования биологически активных бактериальных гидролизатов для нутритивной поддержки населения с растройствами иммунной системы // Пищевая наука и технология. 2015. № 2(31). C. 18-25. DOI: $10.15673 / 2073-8684.31 / 2015.44263$

5. Ликопид (ГМПД) - современный отечественный высокоэффективный иммуномодулятор / Т. М. Андронова, Б. В. Пинегин, И. Г. Козлов. 4-е изд., доп. и перераб. М., 2008. -24 с.

6. Производные мурамилдипептида в клинике / А.В. Караулов и др. // Актуальные вопросы клинической медицины. 2002. Т. 2. C. 93-100.

7. The first ferrocene analogues of muramyldipeptide / Lidija Barišić et al. // Carbohydrate Research. 2011. V. 346(5). P. 678-84 DOI: 10.1016/j.carres.2011.01.006

8. Гаврилин М.В., Сеньчукова Г.В., Сенченко С.П. Выбор оптимальных условий получения гидролизатов молочнокислых бактерий термокислотным способом // Хим.-фарм. журн. 2007. Т. 41, № 2. С. 54-56.

9. Изучение состава препарата, полученного на основе гидролизата молочнокислых бактерий / Сенченко С.П. и др. // Хим.фармац. журн. Т.39. №3. 2005. С. 51-53

10. Гаранян Г.С., Ханферян Р.А., Оганесян Э.Т. Химическое обоснование и биологическое исследование гидролизата на основе культур молочнокислых бактерій // Хим.-фармац. журн. Т.44. №8. 2010. С. 46-49.

11. Ku"hner, D., Stahl, M., Demircioglu, D.D., Bertsche, U. From cells to muropeptide structures in 24 h: Peptidoglycan mapping by UPLC-MS. // Sci. Rep. 2014. V. 4. P. 74-94. DOI:10.1038/srep07494

12. Analysis of the Peptidoglycan Hydrolase Complement of Lactobacillus casei and Characterization of the Major c-D-Glutamyl-L-LysylEndopeptidase / Regulski K. // PLoS ONE. 2012. V. 7(2). e32301. DOI:10.1371/journal.pone.0032301

13. Requirement of Autolytic Activity for Bacteriocin-Induced Lysis / Martinez-Cuesta M.-C. et al. // Applied and environmental microbiology. 2000. Aug. P. 3174-3179 DOI: 10.1128/AEM.66.8.3174-3179.2000

14. Simova E., Beshkova D. Effect of growth phase and growth medium on peptidase activities of starter lactic acid bacteria // Le Lait, INRA Editions. 2007. V. 87 (6). P. 555-573. DOI: 10.1051/lait:2007036

15. Regulski K, Courtin P, Meyrand M, Claes IJJ, Lebeer S, et al. (2012) Analysis of the Peptidoglycan Hydrolase Complement of Lactobacillus casei and Characterization of the Major c-D-Glutamyl-L-Lysyl-Endopeptidase. PLoS ONE 7(2): e32301. doi:10.1371/journal.pone.0032301

16. Биохимия белков: практикум для студентов биол. Фак. спец. 1-31 0101 «Биология» / И. В. Семак, Т. Н. Зырянова, О. И. Губич. Минск: БГУ, 2007. 49 с.

17. Математическое моделирование процессов пищевых производств: Сб. задач: Уч. пособие / Н.В. Остапчук, В.Д. Каминский, Г.Н. Станкевич, В.П. Чучуй. К.: Вища школа, 1992. - 175 с.

18. Kapustian A., Cherno,N. Obtaining and characteristic of the autolysate of lactic acid bacteria // EUREKA: Life Sciences. 2018. V.1. P. 24-31. DOI: $10.21303 / 2504-5695.2018 .00558$

19. Wood B.J., Warner P. J. Genetics of Lactic Acid Bacteria. 2012.

20. ИК-спектры основных классов органических соединений / Б.Н. Тарасевич. М., 2012. 54 с.

21. Кушнір B.I. Фармако-токсикологічна характеристика імуностимулюючого препарату на основі пептидогліканів: дис. ... канд. вет. наук: 16.00.04: захист 25.05.2018 / наук. кер. Брезвин О. М. Львів: Львівський національний університет ветеринарної медицини та біотехнологій імені С. З. Гжицького, 2017. 172 с.

\section{References:}

1. Traub, S. (2006). MDP and other muropeptides - direct and synergistic effects on the immune system. J. Endotoxin Res. 12(2), 69-85. DOI:10.1179/096805106X89044

2. Matsui, K., Ikeda R. (2014). Peptidoglycan in combination with muramyldipeptide synergistically induces an interleukin-10-dependent T helper 2-dominant immune response. Microbiol Immunol. 58, 260-265. DOI:10.1111/1348-0421.12139 


\section{Одеська начіональна академія харчових технологій \\ ЕНЕРГОЕФЕКТИВНІСТЬ.}

\section{РЕСУРСОЗБЕРІГАЮЧІ ТА ЕКОЛОГІЧНО-БЕЗПЕЧНІ ЕНЕРГОТЕХНОЛОГІЇ}

3. Cherno, N., Kapustyan, A. (2016). Immunological properties of the bacterial origin compounds. Food science and technology. 10(3), 1928. DOI: http://dx.doi.org/10.15673/fst.v10i3.175

4. Kapustyan, A. I. CHerno, N. K. (2015). Perspektivy ispol'zovaniya biologicheski aktivnyh bakterial'nyh gidrolizatov dlya nutritivnoj podderzhki naseleniya s rastrojstvami immunnoj sistemy. Pishchevaya nauka i tekhnologiya. 2(31), 18-25. DOI: 10.15673/2073$8684.31 / 2015.44263$

5. Andronova, T.M., Pinegin, B.V., Kozlov, I.G. (2008). Likopid (GMPD) - sovremennyiy otechestvennyiy vyisokoeffektivnyiy immunomodulyator. 4-e izd., dop. i pererab. M. 24.

6. Karaulov, A.V. (2002). Proizvodnyie muramildipeptida v klinike. Aktualnyie voprosyi klinicheskoy meditsinyi. 2, 93-100

7. Lidija Barišić et al. (2011). The first ferrocene analogues of muramyldipeptide. Carbohydrate Research. 346(5), 678-84. DOI: 10.1016/j.carres.2011.01.006

8. Gavrilin, M.V., Sen'chukova, G.V., Senchenko, S.P. (2007). Vybor optimal'nyh uslovii polucheniya gidrolizatov molochnokislyh bakterii termokislotnym sposobom. Him.-farm. Zhurn, 41, 2, 54-56.

9. Senchenko, S.P. Samoilov, V.A., Gostisheva, N.M., Sen'chukova, G.V., Gavrilin M.V. (2005). Izuchenie sostava preparata, poluchennogo na osnove gidrolizata molochnokislyh bakterii. Him.-farmac. Zhurn, 39, 3, 51-55.

10. Garanyan, G.S. Hanferyan, R.A., Oganesyan, E.T. (2010). Himicheskoe obosnovanii i biologicheskoe issledovanie gidrolizata na osnove kul'tur molochnokislyh bakterii. Him.-farmac. Zhurn., 44, 8, 46-49.

11. Ku "hner, D., Stahl, M., Demircioglu, D.D., Bertsche, U. (2014). From cells to muropeptide structures in 24 h: Peptidoglycan mapping by UPLC-MS. Sci. Rep. 4, 74-94. DOI:10.1038/srep07494

12. Regulski, K. (2012). Analysis of the Peptidoglycan Hydrolase Complement of Lactobacillus casei and Characterization of the Major cD-Glutamyl-L-Lysyl-Endopeptidase. PLoS ONE. 7(2). e32301. DOI:10.1371/journal.pone.0032301

13. Martinez-Cuesta, M.-C. et al. (2000). Requirement of Autolytic Activity for Bacteriocin-Induced Lysis. Applied and environmental microbiology. Aug,. 3174-3179 DOI: 10.1128/AEM.66.8.3174-3179.2000

14. Simova, E., Beshkova, D. (2007). Effect of growth phase and growth medium on peptidase activities of starter lactic acid bacteria. Le Lait, INRA Editions. 87 (6), 555-573. DOI: 10.1051/lait:2007036

15. Regulski, K, Courtin, P, Meyrand, M, Claes, IJJ, Lebeer, S, et al. (2012) Analysis of the Peptidoglycan Hydrolase Complement of Lactobacillus casei and Characterization of the Major c-D-Glutamyl-L-Lysyl-Endopeptidase. PLoS ONE. 7(2): e32301. doi:10.1371/journal.pone.0032301

16. Semak, I.V., Zyiryanova, T.N., Gubich, O.I. (2007). Biohimiya belkov: praktikum dlya studentov biol. Fak. spets. $1-310101$ «Biologiya», Minsk: BGU, 49.

17. Ostapchuk, N.V., Kaminskiy, V.D., Stankevich, G.N., Chuchuy, V.P. (1992). Matematicheskoe modelirovanie protsessov pischevyih proizvodstv: Sb. zadach: Uch. Posobie. K.: Vischa shkola, $175 \mathrm{~s}$.

18. Kapustian A., Cherno, N. (2018). Obtaining and characteristic of the autolysate of lactic acid bacteria. EUREKA: Life Sciences. 1, 24-31. DOI: $10.21303 / 2504-5695.2018 .00558$

19. Wood, B.J., Warner, P.J. (2012). Genetics of Lactic Acid Bacteria.

20. Tarasevich, B.N. (2012). IK-spektryi osnovnyih klassov organicheskih soedineniy. Moskva, 54.

21. Kushnir, V.I. (2017). Farmako-toksy`kologichna xarakterystyka imunostymulyuyuchogo preparatu na osnovi pepty`doglikaniv: d`s. ... kand. vet. nauk: 16.00.04: zaxyst 25.05.2018 / nauk. ker. Brezvyn O. M. Lviv: L`vivs`ky`j nacional`ny`j universy`tet vetery`narnoyi medy`cy`ny` ta biotexnologij imeni S.Z. G`zhy`cz`kogo, 172 .

Отримано в редакцію 25.05.2018

Received 25.05.2018

Прийнято до друку 30.06.2018

Approved 30.06.2018 